МЕТОДИЧНІ РЕКОМЕНДАЦІЇ НАУКОВО-ПЕДАГОГІЧНОМУ СКЛАДУ ЩОДО ЗАСТОСУВАННЯ ІМІТАЦІЙНОГО МОДЕЛЮВАННЯ У ПРОЦЕСІ ПРОФЕСІЙНОЇ ПІДГОТОВКИ МАЙБУТНІХ ОФІЦЕРІВ-СУХОПУТНИКІВ ТАКТИЧНОГО РІВНЯ У ВИЩИХ ВІЙСЬКОВИХ НАВЧАЛЬНИХ ЗАКЛАДАХ

\title{
METHODICAL RECOMMENDATIONS RESEARCH AND TEACHING STAFF APPLICATION SIMULATION MODELING DURING VOCATIONAL TRAINING FUTURE OFFICERS-LAND FORCE TACTICAL LEVELS IN HIGHER MILITARY EDUCATIONAL INSTITUTIONS
}

УдК [378:147+371.26]:004:001:355 DOI https://doi.org/10.32843/2663-60852020-20-2-14

\section{Koc M.B.,}

викладач компанії

«Alion Science and Technology»

Національної академії сухопутних

військ імені гетьмана

Петра Сагайдачного

\begin{abstract}
Стаття присвячена проблемам профоесійної підготовки майбутніх офріцерівсухопутників тактичного рівня в Україні. у вступі автор розкрив актуалізував проблему профресійної підготовки майбутніх офріцерських кадрів в Україні. У розділі щодо аналізу наукової літератури досліджено джерела вітчизняних та українських вчених, які вивчали особливості використання технології імітаційного моделювання в освітньому процесі. Першочергово проаналізовано праці західної наукової школи, що вважається основоположником згаданої технології. Автор зазначив, що технологія імітаційного моделювання не $є$ поширеною у підготовці офріцерських кадрів в Україні, а тому потребує на особливу увагу. Сфрормульовано мету наукової публікації.

у викладі основного змісту матеріалу визначено сутність імітаційного моделювання. Виокремлено й обгрунтовано зміст основних методичних рекомендацій щодо використання технології у підготовці майбутніх офрічерів-сухопутників тактичного рівня: забезпечення принципу спільного емоційного-психологічного «проживання» тих ситуацій, що розглядають курсанти; формування змістоутворюючих мотивів в освітній діяльності майбутніх офріцерівсухопутників тактичного рівня; забезпечувати діалогову та психотехнічну взаємодію між викладачами та курсантами; сприяти розвитку як кожного курсанта так і курсантського колективу завдяки парній взаємодії викладачів і курсантів; забезпечення стану «комфортного середовища» у процесі використання технологій імітаційного моделювання; акцентування уваги на розвитку рефрлексії курсантів, тобто забезпечення регулярної самооцінки та самоконтролю курсантами (здійснення самоаналізу щодо власних дій та дій оточуючих).

Сфрормульовано висновки та перспективи подальших наукових досліджень представленої проблеми.
\end{abstract}

Ключові слова: майбутні офріцери-сухопутники тактичного рівня, профресійна підготовка, імітаційне моделювання, технологія.

The article is devoted to the problems of professional training of future tactical ground officers in Ukraine. In the introduction, the author revealed the actual problem of professional training of future officers in Ukraine. The section on the analysis of scientific literature explores the sources of Ukrainian and Ukrainian scientists who studied the peculiarities of the use of imitation modelling technology in the educational process. The works of the Western scientific school, which is considered to be the founder of the mentioned technology, are analysed first. The author noted that imitation modelling technology is not widespread in officer training in Ukraine, and therefore needs special attention. The purpose of the scientific publication is formulated.

The main content of the material defines the essence of simulation. The content and main content of the basic methodological recommendations on the use of technology in training future ground officers of tactical level are distinguished and substantiated: ensuring the principle of joint emotional-psychological "living" of those situations considered by the cadets; the formation of meaningful motives in the educational activities of future tactical-level ground officers; to provide dialogue and psychotechnical interaction between teachers and cadets; to promote the development of each cadet and cadet team through the pair interaction of teachers and cadets ensuring the state of "comfortable environment" in the process of using simulation modelling technologies; emphasis on the development of cadets 'reflection, that is, ensuring regular selfassessment and self-control of the cadets (selfexamination of their own and others' actions). The conclusions and perspectives of further scientific researches of the presented problem are formulated.

Key words: future tactical-level land officers, training, imitation modelling, technology.
Постановка проблеми у загальному вигляді. Проблема оптимізації освітнього процесу не $\epsilon$ новою для української системи вищої освіти. У наукових джерелах існує чимало інсоормації щодо шляхів, змісту, особливостей та цілей згаданого вище процесу. Наша увага зосереджена на такій технології як імітаційне моделювання, зокрема використання ії у професійній підготовці майбутніх офріцерів-сухопутників тактичного рівня. Військова освіта, як і освіта цивільних фрахівців, потребує в Україні суттєвого рефрормування. Армія є тим соціальним утворенням, без якого суспільство не зможе забезпечити ні свою соціальну структуру, ні соціальне переміщення ії членів, ні фрундаментальну взаємодію між усіма соціальними інститутами. Український системи вищої військової освіти необхідно активно використовувати досягнення як вітчизняної, так і зарубіжної педагогічної інноватики. Саме імітаційне моделювання $є$ такою новітньою освітньою технологією.

Аналіз останніх досліджень і публікацій. Якість проведення наукового пошуку полягає 
у глибинному вивченні проблеми, що досліджується у бібліографрічній базі. Нині є чимало наукових інфрормаційних джерел, з якими доцільно ознайомитись. Враховуючи те, що українська освітня система розвивається у контексті європейської, ми звернули увагу на зарубіжну наукову літературу щодо застосування імітаційного моделювання у вищій школі.

Канада є досить активною у використанні технологій імітаційного моделювання. Дослідники А. Мазур, Б. Браун, М. Якобсен [3] є прихильниками цієї технології, оскільки сприймають ії як можливість покращення оперативності навчальної діяльності студентів.

Іспанський вчений Б. Рісінг у наукових публікаціях подає опис імітаційних ігор у підготовці майбутніх фрахівців [4].

Американський науковець Дж. Стайєр присвятив докторську дисертацію порівняльному аналізу традиційних методів навчання та імітаційних [5].

У вітчизняній педагогічній науці можна згадати прізвища В. Вонсовича, який вивчав вплив імітаційних технологій у навчально-професійній діяльності студентів [1].

Варті уваги праці О. Сергеєвої, Т. Дубовик, які досліджували вплив тренажерів в освітньому середовищі [2].

Виділення не вирішених раніше частин загальної проблеми. Історія неодноразово демонструвала, яким чином важливі події можуть вплинути на розвиток тієї чи іншої соціальної сфрери. Дії сусідньої з Україною країни, переважно агресивні, змусили переглянути концепцію підготовки.

Мета статті - сорормулювати зміст методичних рекомендацій щодо використання імітаційного моделювання у професійній підготовці майбутніх офріцерів-сухопутників тактичного рівня.

Виклад основного матеріалу. Пріоритетна місія сучасної освіти, зокрема вищої військової забезпечення високого рівня її якості. Однією з ознак сучасного наукового розвитку є застосування досягнень однієї сфери у іншій сорері. Яскравим підтвердженням цьому є метод імітаційного моделювання, що першочергово виник в економічному середовищі, а з часом був упроваджений у педагогічне.

Система підготовки майбутніх офріцерів в Україні ще має залишкові ознаки попередньої радянської. У зв'язку із цим посадовці державного рівня формулюють вимоги щодо перетворення згаданої системи за зразками успішних армій країн світу. Блок НАТО активно використовує технології імітаційного моделювання у підготовці та перепідготовці своїх фрахівців.

Узагальнено про імітаційне моделювання можна стверджувати таким чином: перенесення майбутнього фрахівця у професійну діяльність, тобто забезпечення їм квазіпрофресійної атмосфрери в освітньому процесі.
Імітаційне моделювання у педагогічній науці має статус технології активного навчання.

Особливості професійної підготовки майбутніх офріцерів-сухопутників тактичного рівня полягають у потребі проміжного стану між освітньою діяльністю та майбутньою професійною, тому імітаційне моделювання використовується 3 метою трансорормації одного виду діяльності в іншій. Широта профресійній функцій офріцерів-сухопутників тактичного рівня вимагають розгляду чималої кількості проблемних ситуацій творчого, розвивального та професійного змісту.

Значення імітаційного моделювання у підготовці майбутніх офріцерів-сухопутників тактичного рівня випливає зі змісту та особливостей їх діяльності, а саме:

- запобігання, ліквідація загроз національній безпеці української держави;

- проведення протидесантних операцій;

- проведення спеціальних операцій;

- забезпечення протиповітряної оборони;

- забезпечення територіальної оборони;

- проведення антитерористичних операцій тощо.

3 огляду на подане вище (характер профресійної діяльності) та сутність імітаційного моделювання, нами виділено основні методичні рекомендації представникам науково-педагогічного складу вищих військових навчальних закладів щодо застосування цієї технології у підготовці майбутніх офріцерів-сухопутників тактичного рівня:

1. Орієнтуватись на зміст професійної діяльності офріцерів-сухопутників тактичного рівня.

2. Забезпечувати наближення специсічних професійних положень у підготовці майбутніх ооріцерів-сухопутників (теорії, парадигми, знання, принципи) до реалій фрахової сорери.

3. Виконання завдань здійснювати за такою послідовністю: від пріоритетної проблеми, від наявних у курсантів теоретичних знань, від аналізу проблеми, від очікуваного результату, від аналізу результату, від осмислення отриманих результатів.

4. Використання групового принципу у вирішенні проблеми, тобто забезпечення принципу співпраці між викладачами та курсантами, а не фрормулювання готового рішення відповідної проблеми.

5. Здійснення правильного відбору фрілософрських, психологічних, дидактичних положень, на яких базується проектування відповідної імітаційної моделі.

6. Врахування структури, складності та цілісності об'єктів, що моделюються.

7. Несуперечливе відображення в побудованій моделі усіх її закономірностей та обмежень.

8. Забезпечення принципу спільного емоційного-психологічного «проживання» тих ситуацій, що розглядають курсанти. 
9. Звертати увагу на формування змістоутворюючих мотивів в освітній діяльності майбутніх офріцерів-сухопутників тактичного рівня.

10. Забезпечувати діалогову та психотехнічну взаємодію між викладачами та курсантами.

11. Сприяти розвитку як кожного курсанта так і курсантського колективу завдяки парній взаємодії викладачів та курсантів.

12. Забезпечення стану «комфортного середовища» у процесі використання технологій імітаційного моделювання.

13. Акцентування уваги на розвитку ресрлексії курсантів, тобто забезпечення регулярної самооцінки та самоконтролю курсантами (здійснення самоаналізу щодо власних дій і дій оточуючих).

Запропоновані вище методичні рекомендації потребують внесення певних коректив, оскільки вони створені із урахуванням специфріки професійної діяльності майбутніх офіцерів-сухопутників, а також того фракту, що педагогічна наука знаходиться у постійному пошуку та розвитку і пропонує оновлені або транссрормовані варіанти тих чи інших освітніх технологій.

Важливим $€$ те, що імітаційне моделювання дає змогу поглибити професіоналізацію згаданих вище офріцерів. Можна констатувати, що науковопедагогічний склад вищих військових навчальних закладів має можливість створювати квазіпрофресійну модель для офріцерів завдяки імітаційному моделюванню, що в свою чергу розширює їх теоретичну та поглиблює практичну базу.

Висновки. Отже, використання імітаційного моделювання у професійній підготовці майбутніх офріцерів-сухопутників тактичного рівня уможливлює забезпечення формування їх випереджувального професійного досвіду. Цінним у застосуванні технологій імітаційного моделювання $€$ формування саме професійного мислення майбутніх офріцерських кадрів сухопутних військ, а також компетентності, світогляду та культури.
Багатогранність професійної діяльності майбутніх офріцерів-сухопутників тактичного рівня, складність умов виконання професійних обов'язків, змінність професійних ситуацій та їх нестандартність, вимагають від згаданих офріцерів високого рівня оперативності та вміння приймати відповідні рішення.

У подальших наукових дослідженнях доцільно вивчити, які саме технології імітаційного моделювання та для яких навальних дисциплін вищих військових навчальних закладів варто розробити. Ще одним цінним дослідженням $є$ вивчення досвіду поєднання технологій імітаційного моделювання з іншими інноваціями або традиційними освітніми технологіями.

\section{БІБЛІОГРАФІЧНИЙ СПИСОК:}

1. Вонсович В.П. Використання імітаційних технологій і прийомів у навчально-професійній діяльності студентів. URL: http://www.nbuv.gov.ua/ portal/ Soc_Gum/Vchu.

2. Сергеева О.В., Дубовик Т.Н. Использование тренажеров для учебной среды. Вісник Черкаського державного технологічного університету. Серія : Технічні науки. 2010. № 3. С. 136-140. URL: http://nbuv.gov.ua/UJRN/Vchdtu_2010_3_29.

3. Mazur, A.D., Brown, B., Jacōbsen, M. (2015). Learning designs using flipped classroom instruction. Canadian Journal of Learning \& Technology, 41(2), 1-26.

4. Rising, B. (1999). La eficacia didáctica de los juegos de simulación por ordenador en el aprendizaje del inglés como lengua extranjera en alumnos de Derecho, Económicas e Ingeniería [The effectiveness of telematic simulation games in EFL for Law, Economics, and Engineering] (Doctoral thesis). Universidad Pontificia Comillas, Madrid, Spain.

5. Strayer, J.F. (2007). The effects of the classroom flip on the learning environment: A comparison of learning activity in a traditional classroom and a flip classroom that used an intelligent tutoring system (Doctoral dissertation). The Ohio State University, Columbus. 